\title{
Full range of measures of the system of legal support and surveillance activities aimed at ensuring economic security of entrepreneurship
}

\author{
Peter Ivanov ${ }^{1,2}$, Anatoliy Kustov ${ }^{2}$, Elwira Nadyseva ${ }^{1, *}$ \\ ${ }^{1}$ Moscow Region State University, 10A, Radio str., 105005, Moscow, Russia \\ ${ }^{2}$ Research Center of Academy of Management of the Ministry of Internal Affairs of Russia, 8, Zoe \\ and Alexander Kosmodemyanskikh str., 125993, Moscow, Russia
}

\begin{abstract}
Business area is an integral part of state's economy. An entrepreneur, who undertakes their activities legally, participates in the development of a material product, significantly contributes to the improvement of people's purchasing power and pays taxes to the state budget. In this regard, the government must protect entrepreneurial activities, create favorable conditions to attract citizens into this economy sector. Today business area is associated with a set of actual risks and threats, which include market monopolization, criminalization of a number of economy sectors and parties of business activities, administrative burdens, fraudulent actions taken by certain employees of commercial entities, drawbacks in statutory regulation. Current demand for the optimization of entrepreneurship proves the relevance of elaborating a full range of measures associated with a system of legal support and surveillance activities and aimed at ensuring economic security of this area. Today such a system is particularly demanded due to high crime rate and several other factors taking place in the field of entrepreneurship.
\end{abstract}

\section{Introduction}

Analysis of the results of various studies in the field of ensuring the security of entrepreneurship showed that it is impossible to reduce the crime rate in this area without the inclusion into the system of economic security ensuring of law enforcement and legal components, which together comprise the core of timely detection and neutralization of deeply hidden determinants that affect the spread of crimes, mainly those of economic and corruption orientation. The need for ensuring security is reasoned by a combination of interrelated factors, the main of which is the presence, along with legal activities of economic entities (entrepreneurs), of criminal entrepreneurship that is focused on extracting income, which is further used to reproduce criminal business.

The purpose of this study is to elaborate scientifically based approaches to the development of a system of legal and law enforcement support for economic security of

\footnotetext{
* Corresponding author: doptaganka@yandex.ru
} 
entrepreneurship. The system being developed consists of a set of measures corresponds to the contemporary reality.

\section{Materials and methods}

When studying the problems of ensuring legal and law enforcement support for entrepreneurship, the authors applied general scientific methods that include formal logical ones (analysis, synthesis, generalization, abstracting, hypothesizing) and specific scientific methods such as observation, questionnaires, interviews and analysis of documents' content. Combination of these methods allowed achieving a certain scientific result and drawing up conclusions and suggestions for improving the legal and surveillance support for entrepreneurial activity [1-4].

\section{Results}

The authors scrutinized patterns of the system of legal and surveillance support for the economic security of entrepreneurship and proceeding from it chose an optimal set of measures aimed at increasing the effectiveness of entrepreneurial activity. The set of measures was scientifically justified. The authors believe that criminological research into causes and conditions of these types of crime allows developing recommendations that would help eliminate them. At the same time, the authors consider it appropriate to address and work out the issue of improving regulatory arrangement of implementation of the surveillance system for ensuring economic security in business.

Business activity is understood as the initiative activity of an economic entity for a specific purpose. Business activity is associated with the use of property, money and other resources for achieving commercial and other type of success based on a combination of personal and public benefits. Dictionaries define the scope of activity as the type of work and services provided for in a corporate charter of an organization or enterprise. Of course, this situation also applies to the sphere under consideration.

The main traits (features) of behavior pattern inherent in entrepreneurship are the following: business activities are mainly aimed at making profit from using property, selling goods, performing work and providing services. As one can see, this refers to economic activity that is not prohibited by law. Such an activity is performed in accordance with current law for the purpose of creating material goods and comforts. It comprises a number of economy sectors that suggest products in the form of goods, works and services. Moreover, various production and economic activities, and particularly the activity under consideration are carried out at their own liability to the extent determined by the legal form of the enterprise (state, municipal, unitary, public (private) joint-stock company, partnership, individual enterprise, production cooperative).

The system of criminal intelligence and surveillance support for economic security of entrepreneurship includes a set of actions performed by the agencies that execute surveillance activities in cooperation with other law enforcement bodies and other interested organizations and aimed at taking theoretical, regulatory, organizational, informational, analytical, tactical, coordination and methodological measures that are to stabilize the criminal situation in entrepreneurship. In other words, this refers to a set of risks and threats that entail the possibility of harm affecting the investment climate of entrepreneurial activity and caused by economic and corruption offenses and crimes. Organized economic crime associated with corruption still remains one of the most dangerous threats to entrepreneurship. 
The named system consists in a full range of measures that are primarily aimed at minimizing the likelihood of doing harm to business. At the same time, a full range of measures is a set of actions undertaken by the agencies engaged in surveillance activities in accordance with the criminal intelligence and surveillance legislation in order to create conditions required for further development of entrepreneurship in the country and displacement of its illegal part that extracts criminal income.

We suppose that the system of surveillance support for economic security in the sphere of entrepreneurial activity is an integral part of the Economic Security Strategy of the Russian Federation for the period up to 2030 [5], since the challenges and threats to economic security that are mentioned in this document (high level of criminalization and corruption, preservation of a significant share of the grey economy) are inherent in this area and, as many years of law enforcement practice show, cannot be neutralized and minimized without the use of forces, money, methods and forms of surveillance activity.

We believe that surveillance support for the economic security of entrepreneurial activity firstly should be based on the constant monitoring of risks and threats that arise, particularly of those that result from crimes of an economic and corruption nature committed. This is the challenge facing the bodies that carry out crime intelligence activities. At the same time, these bodies interact with public and local authorities, civil society institutions and the media. It is worth noting that in the law enforcement system, these bodies act as the head office for organizing surveillance support for economic security, including the sphere of entrepreneurship. In our opinion, this is their main function.

The existing system of surveillance support for economic security is aimed at preventing threats to economic security that create a direct or indirect possibility of harming economic interests of entrepreneurs. At the same time, such a system should contribute to compliance with legislation on the protection of property of honest entrepreneurs from criminal attacks, their economic interests; increasing the level of transparency of financial and economic activities in the considered segment of the economy, particularly with the use of a mechanism for defining beneficial owners of business entities; timely prevention of misuse of budget funds allocated to business structures primarily for the implementation of state programs and large investment projects. Thus, the efficiency of using these funds is to be increased.

Methodological measures are mainly aimed at solving the following key problems: defining a linked dependence of economic crime, corruption and organized criminal activity, which should be investigated as an integral part of general crime. Scientific provisions are based on the study of patterns of both the phenomenon itself and the environment of its manifestation. Through the study of a combination of factors, including anti-crime ones, it is necessary to try to reach yet unknown patterns; pattern of linked dependence in the context of independent social and legal phenomena are to be perceived. Moreover, it is important to track the dialectics of the development of a market economy, organized crime and corruption; the choice of effective general scientific methods for cognition of economic crime associated with corruption and organized criminal activity (this type of crime is the object of the research). Thus, it is easier to comprehend the phenomenon under investigation.

In our opinion, regulatory measures including civil law, administrative law, criminal law, criminal procedure, criminological law should take a significant place in the system under consideration.

It is worth noting in the aspect being studied that in the Code of the Russian Federation on administrative offenses (dated December 30, 2001 No. 195-FZ), the whole chapter 14 is devoted to administrative offenses in the field of entrepreneurial activity and the activities of self-regulatory organizations. This chapter contains 64 articles establishing liability for 
various administrative offenses. Law enforcement bodies, by their inherent forces and means, take measures to implement these standards.

As for the criminal law measures, the following prohibitions contained in them are worth mentioning: to carry out entrepreneurial activity without registration or without a license in cases when such a license is required, if this act caused major damage to citizens, organizations or the state or is associated with extraction of large income (illegal entrepreneurship - Article 171 of the Criminal Code of the Russian Federation); production, purchase, storage, transportation or sale of goods and products without corresponding marking and (or) putting information required by the legislation of the Russian Federation (Article 171.1 of the Criminal Code of the Russian Federation); illegal organization and conduct of gambling games (Article 171.2 of the Criminal Code of the Russian Federation); illegal production and (or) trafficking of ethyl alcohol, alcoholic and alcohol-containing products (Article 171.3 of the Criminal Code of the Russian Federation); illegal retail sale of alcoholic and alcohol-containing food products (Article 171.4 of the Criminal Code of the Russian Federation).

The above-listed criminal law prohibitions are referred to chapter 22 of the Criminal Code of the Russian Federation "Crimes in the field of economic activity". In addition to the aforementioned regulations, the agencies carrying out criminal intelligence and surveillance operations, take into account in their activities the possibility of: considering circumstances precluding the criminal nature of an act (Chapter 8 of the Criminal Code of the Russian Federation); exemption from criminal liability and punishment (section $1 \mathrm{U}$ of the Criminal Code of the Russian Federation); forced gratuitous seizure and appeal to state ownership on the basis of a guilty verdict (confiscation of property - Article 104.1 of the Criminal Code of the Russian Federation).

Speaking of regulatory measures, one cannot fail to note at least one example of their improvement. The regulation of credit organizations and investment companies, which today is significantly affected by financial technologies related to digital (virtual) currency, needs to be improved. Y.V. Truntsevsky rightly notes that "the world of banking and financial services continues to change rapidly and dramatically, alternatives to traditional products and services are introduced daily, which significantly affects the use of money: new markets are being created" [6]. It seems that the use of digital currencies as a financial instrument outside the legal field certainly poses an increased risk, for example, when laundering money in the financial sector.

We believe that the priority task today is to take legislative and other measures aimed at prohibition for persons who have an outstanding conviction for economic or public-order crimes, to participate in beneficial ownership of organizations engaged in shady operations with money and other property. The successful solution of this problem implies the increase in professional training of law enforcement officers [7] and, first of all, of agencies performing surveillance activities, in order to intensify the combat against economic crimes, particularly by means of counteracting the legalization (laundering) of revenue gained by illegal means, and the financial support of terrorism. In this regard, of the particular interest is the viewpoint of E.P. Shlyakhtin, who proposes to introduce a practiceoriented approach to teaching criminal intelligence disciplines [8]. Improving the educational level of agencies performing surveillance activities in combating, for example, high-tech crime is impossible without advancing the vocational education system based on modern scientific and technological achievements [9].

We think, that organizational measures comprise a relatively independent group [10]. These measures are aimed at: implementing state policy in the field of ensuring economic security [4], including the sphere of entrepreneurial activity. The aforementioned state policy defines goals, main directions and tasks. According to the authors, the goals include the one implying the increase in stability of this sphere to the effects of external and 
internal challenges and threats. Currently, when national projects are being implemented, the main threat consists in the embezzlement and misuse of public funds. Commercial structures are known to be ordinarily involved in these acts of corruption; to entrust the function of assessing threats to economic security arising as a result of shady operations (transactions) involving budgetary funds or other property, to develop measures aimed at countering these threats, to the Federal Financial Monitoring Service (Rosfinmonitoring) [11], which has a tested and proven methodology and mechanism for its implementation; to create a unified information system in the field of combating the misuse and theft of public funds, corruption, shadow and criminal economies; to improve the mechanism for participation in the activities of the proposed system of non-governmental organizations performing surveillance activities aimed to protect budget funds from criminal offences. These organizations are advised to identify budget beneficiaries engaged in shady operations with funds and other property. It is well-known that such operation lead to unjustifiable enrichment. Given this, Y.V. Truntsevsky proposes (we share his viewpoint) to consider the possibility of criminalizing unjust enrichment and money misuse as a predicate offense that relates to money laundering, as well as the possibility of confiscations.

As we assume, the next group in the considered set of actions consists of informational measures, the adoption of which should contribute to the expansion of information technology capabilities of bodies performing surveillance activities in collection, timely processing, analysis, storage and transfer to criminal intelligence units of information on crimes related to crimes related to the legalization of illegal incomes (at the same time creating necessary conditions for expanding the practice of additional labelling of processes performed by suspects (accused defendants) in accordance with Articles 174, 174.1 of the Criminal Code of the Russian Federation in the investigation of criminal cases of predicate crimes), as well as on crimes related to the conclusion of agreements that restrain competition, which are prohibited by antitrust legislation.

Thus, active introduction of digital methods of accounting, collection, storage, processing, transformation and transmission of information is a promising direction. The implementation of the program of digitalization of the Russian economy also guides this, as is also stated in the decree of the President of the Russian Federation, which approved the Strategy for the Information Development of the Society: "The digital economy is an economic activity, the key production factor of which is digital data, processing of large scope of which as well as the use of results of their analysis can significantly increase the efficiency of various types of production, technologies, equipment, storage, sale a delivery of goods and services, if comparing with traditional forms of management" [11].

At the same time, it should be kept in mind that digitalization poses certain threats besides giving positive effect. Recently, there has been an increase in crimes committed with the use of information technology. Experts note that "as digitalization develops in conditions of social differentiation, we will observe an increase in traditional economic crime, but new forms of crime related to cybercrime will also develop. Cybercrimes will become crueler and more sophisticated" [12]; the use of information received from the Internet [13], in the interests of timely detection and suppression of economic and corruption crimes. As practice shows, as far as modern information and telecommunication technologies are being used more widely, cases of fraud are becoming more frequent. In order to promptly and timely stop such crimes, one may obtain significant information from social networks, instant messaging services, emails and payment systems. Digital information stays saved for a long time, which makes it possible to efficiently fulfill tactical missions that arise when detecting, preventing and solving economic crimes committed with the use of the Internet, including acts of identifying the event of crime and persons who committed it. This became possible due to the introduction of the Unified Biometric 
System, which is a digital platform for remote biometric identification of citizens by their voice and face image. This platform was launched in 2018.

Along with the measures discussed above, an integral part of the system is the complex of analytical actions. Analytical activity allows: decomposing the system of legal and surveillance support for economic security (the key term) inherent in the process of identifying and suppressing high-latency crimes, which today are crimes of an economic and corruption nature; identifying external factors that negatively impact the fulfillment of surveillance and tactical missions for ensuring the safety of property of bona-fide entrepreneurs; studying surveillance support as an integral entity, consisting of many interconnected elements and parts (goal, tasks, functions, object, subject, system, unit structure, fulfilling this support, principles, measures); seeing stable connections and relationships through "penetrating" into the aforementioned process with the use of general scientific and specific methods (techniques) of analysis; formulating certain patterns inherent in the legal and law surveillance support for economic security; developing a set of measures aimed at restraining the growth of economic and corruption crimes by localizing and neutralizing the causes and conditions entailing them.

These actions primarily are of a surveillance and search nature. They are aimed at: identifying conditions and factors that create a risk and a threat to economic security (illegal withdrawal of funds from legal economic turnover to the criminal sector of grey economy, involvement in legal economic turnover of illegally obtained funds by a legal entity); establishing risk zones with the use of surveillance forces, means and methods (uncommon scale of the transaction, depositing a significant amount of money into the account, the volume of turnover on the accounts of the legal entity significantly exceeds the industry average for structures with the same amount of assets); determination of priority monitoring zones for possible legalization by a business entity of income gained from illegal business, tax evasion ("reference points"). Herewith the points of entry of capital into financial and economic activity and the points of exit out of it should be taken into account. Such a procedure is executed along with discovering carriers of sources of significant information about individuals, facts, events and circumstances related to the modeling of various financial and economic schemes used to legalize criminal income [14]. If necessary, within the framework of the analyzed measure, the bodies carrying out surveillance operations, in accordance with the current relevant legislation, conduct analytical, technical and search intelligence. Not only law enforcement agencies, but also different ministries and departments provide their information systems for the successful performance of tactical missions.

The proposed system includes significant measures of prestrategic (tactical) nature, consisting in predicting complexes of conditions and factors that entail a direct or indirect possibility of harming economic interests of honest entrepreneurs. These measures are to be implemented by developing and conducting a set of surveillance measures, including those restricting constitutional rights of an individual. This refers primarily to risks and threats of various kinds, particularly the following:

a) risks and threats of the grow of grey economy in the field of entrepreneurship, manifested in the form of: intertwining of interests of dealers involved in grey economy, members of organized criminal groups and government officials at the level of common goals and means. This results in the formation of criminal alliances of foreign and Russian "crime partners" for conduct of illegal, essentially criminal foreign trade and currency transactions; functioning of the grey market of professional intermediary services that allow customers to disguise the source of funds and make it impossible to detect the ultimate beneficiary; registration of financial instruments in false names; transferring the experience of national economic crime to transnational economic relations; "triads" - a symbiosis of organized crime, economic crime and corruption; making corruptive contacts and their use 
by sustainable organized structures in order to increase illegal income and strengthen the influence on power structures; criminalization of population's psychology resulted from a sharp social differentiation of society and, therefore, the improvement of professional skills of criminal elements specializing in semi-legal intermediary forms of grey business in foreign economy; grey economy became the basis of criminally acquired capital belonging to organized criminal groups; the area of application of criminally acquired capital is the grey economy; inclusion of corrupt authorities into organized criminal groups through the grey economy;

b) risks and threats for transactions in the field of entrepreneurship, manifested in form of: illegal reimbursement from the budget of large amounts of value added tax; buildings relations by a legal entity, which is a taxpayer, with a nominally legitimate organization (a fly-by-night company), in personal accounts of which large turns are observed; "converting" criminal incomes into legal profit through financial intermediaries (companies specializing in money laundering); illegal flight of capital; embezzlement of budget funds intended for the implementation of targeted programs, major investment and infrastructure projects; misuse of budget funds allocated for the implementation of such national projects as "Housing and urban environment", "Ecology", "Labor productivity and employment support", "Small and medium-sized enterprises and support of individual entrepreneurial initiative";

c) corruption risks and threats of financial and economic operations in the field of entrepreneurship, manifested in the form of: drawing into corruption schemes when executing procurement of products and services for needs of the state or municipality; large-scale and grand bribery, as well as crimes committed by high-ranking officials of state and local authorities; lobbying for vested interest when concluding contracts (agreements); legalization of income gained from corruption crimes; non-observance of restrictions and violation of prohibitions established by the legislation on corruption counteraction; bribery of officials of various state bodies; illegal procurement of material and other benefits and advantages; malpractice, abuse of authority; commercial bribery; giving, receiving a bribe; extortion of money from bidders when placing government orders for securing victory or terminating actions aimed at disrupting tenders; extortion by officials of bribes in the form of "kickbacks" for allocation of budgetary funds to enterprises, for example, housing and communal services;

d) risks and threats of financial and economic operations associated with crimes committed by criminal structures, manifested in the form of: legalization of income derived from tax evasion; organized economic crime involving corruption; the proceeds of criminally obtained funds into the grey economy, both legal and illegal (criminal cycle); establishing, in order to increase the illegal proceeds of monopoly and market control; legal or illegal channels of fundraising in the "shadow" system of the economy to strengthen and expand organized criminal activity; investing illegally acquired capital (criminal investment) in the most profitable sectors of the economy; the use by an unscrupulous taxpayer of a "legitimate" loophole to conceal their income; large-scale financial fraudulent transactions and scams committed by criminal structures related to the use of electronic and telecommunications facilities, especially computer networks; establishment by representatives of the organized criminal business of control over profitable enterprises and individual entrepreneurs; splicing based on the common interests of Russian and transnational organized crime of an economic nature;

e) risks and threats of deals (transactions) related to taxation, manifested in the form of: using an illegal scheme of "business fragmentation"; the confusing or unusual nature of a transaction that does not have an obvious economic meaning or an obvious legitimate aim; inconsistencies of the transaction with the goals of the organization established by the constituent documents of this organization; repeated transactions or transactions, the nature 
of which gives reason to believe that the purpose of their implementation is to evade mandatory control procedures; settlements between the parties to the transaction using the settlement accounts of third parties; multiple contributions by the founders (managers) of funds to replenish the working capital of the organization; adoption by the head of the organization of decisions (conclusion of doubtful transactions with affiliated structures for the sale of property), leading to deliberate bankruptcy; compilation of fictitious primary accounting documents (falsification of signatures, seals and stamps); inconsistencies in original documents of accounting and reporting with actual results of financial and economic activities of the organization; use of enterprises and organizations registered to shill individuals ("fly-by-night companies") for making illegal financial transactions; conclusion of shill commercial deals with controlled legal entities in order to initiate bankruptcy proceedings and get the property of an enterprise; purposeful creation of large debts to creditors and the state; illegal cash withdrawal and moving assets abroad with the subsequent bankruptcy of the organization; introducing deliberately false information into the reporting documentation on volumes of actually performed work according to the concluded state contract and their cost (falsification of completion certificates); inclusion of knowingly false information in the tax return in order to illegally receive money from the federal budget as a reimbursement of value added tax; ignorance of accounting statements; the submission of knowingly false information about the economic situation and financial condition when concluding a loan agreement; illegal alienation of property, property and non-property rights and monetary funds of business entities; overstatement of the cost of purchased equipment, estimates for work performed; inclusion of deliberately distorted data in the acts of acceptance of work performed; taxpayer making multi-way financial and business operations in order to conceal income using affiliated intermediary firms, creditors, suppliers and consumers of their products.

Entities that implement the system of legal and surveillance support for the economic security of entrepreneurial activity want to ensure that financial transactions (deals) made in this area are transparent, that there are as few as possible business entities that perform dubious (uncommon) operations. Only then the aforementioned risks and threats may be minimized, which also will help reduce the economic and corruption crime rate in entrepreneurship. In particular, tactical measures are aimed at finding the optimal model of surveillance support for economic security, the priority of which would be the timely detection and suppression of economic and corruption crimes.

We think that measures of methodological support have a special place in the system of legal and surveillance support for economic security. These measures pursue the following goals: development of methods on the basis of in-depth monitoring for identifying, preventing, revealing and investigating economic and corruption crimes committed by business entities; improving the mechanism of confiscation and other forms of withdrawal of illegal incomes from those who committed crimes, as well as compensation for damage caused by unlawful acts that is to be payed to the state, organizations and individual entrepreneurs providing mediation services; expanding surveillance practices for the purpose of timely identifying and blocking (freezing) assets intended for extremism and terrorism; improvement of control mechanisms for the proper spending of budget funds during its development by attracting commercial structures; generalization of the positive experience in the implementation of law enforcement practice in identifying beneficial owners of business entities that are in their operational service, by the authorities performing surveillance operations, together with Rosfinmonitoring.

Finally, the authors believe that measures of international character have the place of great significance in the system of legal and surveillance support for economic security of entrepreneurship $[15,16]$. Such measures are necessitated by the implementation of international law, for example, in the field of combating bribery of foreign officials in 
accordance with the provisions of the Convention for the Suppression of Bribery of Foreign Officials in International Transactions (hereinafter - the Convention). The Russian Federation joined the Convention on February 1, 2012. The provisions of the Convention require to develop rules that would prevent the creation of hidden accounts, the conclusion and conduct of unaccounted or doubtful transactions, the use of falsified documents.

Unfortunately, organized criminal activity of economic nature has substantially changed, as indicated by the amount of its characteristics. One of these characteristics is transnational criminal cooperation. In order to recognize transnational relations, people working in executive subdivisions of bodies carrying out surveillance should know the totality of the signs indicating this. The main of these signs are: detection of repeated transactions, which seem like their purpose is to evade mandatory control procedures provided by applicable legislation; the potential use of cash uncontrolled by law enforcement and supervisory authorities for the purposes of financing extremist activities and terrorism. As long as "platforms" for servicing grey flows exist, risks do not disappear; sham foreign economic activity of legal entities; the use of foreign legal entities and trusts registered mainly in a country that has preferential taxation; participation of shill legal entities - residents (fly-by-night companies) in chains of financial transactions; unjustified withdrawal of funds abroad (violation of banking legislation and of standards established by the Bank of Russia).

\section{Conclusions}

The study performed allows drawing up the following conclusions.

Firstly, modern conditions require the improvement of the system of legal and surveillance support for economic security in entrepreneurship. This system should become an integral part of the Economic Security Strategy of the Russian Federation for the period until 2030 (adopted by Decree of the President of the Russian Federation of 05.13.2017. No. 208) and the Concept for the development of the national system for counteracting the legalization (laundering) of income gained from crime and the financing of terrorism, approved by the President of the Russian Federation on 05.30.2018

Secondly, we understand the system of legal and surveillance support for economic security of entrepreneurship as a combination of risks and threats that may do harm to this sphere and as certain measures to minimize them. By this day, organized economic crimes committed by those who have corruptive relationship remain one of the most dangerous sources of threats.

Thirdly, the authors believe that the absence of the system of legal and surveillance support for economic security of entrepreneurship that would be adequate to modern reality is a vulnerable factor that entails risks and threats posed to the economic security of business.

Fourthly, this system contains a full range of measures that are aimed primarily at eliminating the causes and conditions facilitating organized economic crimes committed by those having corruptive relationships.

\section{References}

1. A.V. Anosov, Trudy Akademii upravleniya MVD Rossii 4(48) (2018)

2. S.S. Burynin, Bezopasnost' biznesa 1 (2019)

3. N.S. Goncharuk, Bezopasnost' biznesa 1 (2019)

4. A.M. Peresedov, Bezopasnost' biznesa 1 (2019) 
5. On the Economic Security Strategy of the Russian Federation for the period up to 2030: Decree of the President of the Russian Federation dated May 13, 2017 No. 208 // Meeting of the legislation of the Russian Federation, 05/15/2017, No. 20, Article 2902

6. Yu.V. Truntsevskiy, Sbornik statey uchastnikov mezhvedomstvennoy konferentsii «Sovremennaya ekonomicheskaya prestupnost'» posvyashchennyy 70 - letiyu professora V.D. Laricheva (M., 2019)

7. R.V. Pavlenkov, Yuridicheskaya nauka i praktika: Vestnik Nizhegorodskoy akademii MVD Rossii 3(39) (2017)

8. Ye.P. Shlyakhtin, Sbornik statey uchastnikov mezhvedomstvennoy konferentsii «Sovremennaya ekonomicheskaya prestupnost'» posvyashchennyy 70 - letiyu professora V.D. Laricheva (M., 2019)

9. On the Economic Security Strategy of the Russian Federation for the period until 2030: Decree of the President of the Russian Federation dated May 13, 2017 No. 208 // SZ RF. 2017. No. 20. Art. 2902

10. P.I. Ivanov, Trudy Akademii upravleniya MVD Rossii 3(51), 63 (2019)

11. On approval of the Regulation on the Federal Service for Financial Monitoring: Decree of the President of the Russian Federation of June 13, 2012 No. 808

12. On the Strategy for the Development of the Information Society in the Russian Federation for 2017-2030: Decree of the President of the Russian Federation of May 9, 2017 No. 203

13. N.N. Solovykh, Bezopasnost' biznesa 1 (2019)

14. Yu.V. Gavrilin, A.V. Shmonin, Trudy Akademii upravleniya MVD Rossii 1(49) (2019)

15. SZ RF of October 4 40, 3882 (2004)

16. Newsletter "Inter-Parliamentary Assembly of the Commonwealth of Independent States" 16, $222-239$ (1998) 